\title{
KINETIC ANALYSIS AND SIMULATION OF UASB ANAEROBIC TREATMENT OF A SYNTHETIC FRUIT WASTEWATER
}

\author{
V. DIAMANTIS ${ }^{*}$ \\ A. AIVASIDIS
}

Department of Environmental Engineering

Democritus University of Thrace

GR-671 00, Xanthi, Greece
Received: 04/07/08

Accepted: 24/12/09 *to whom all correspondence should be addressed: e-mail: bdiamant@env.duth.gr

\section{ABSTRACT}

An Upflow Anaerobic Sludge Bed (UASB) reactor was used to evaluate mesophilic anaerobic treatment of a pre-acidified fruit wastewater. The system was operated at increasing volumetric loading rates by sequentially increasing wastewater flowrate. The operational temperature was maintained initially at $37^{\circ} \mathrm{C}$ and consequently decreased to 30 and $25^{\circ} \mathrm{C}$. For the volumetric loading rates examined i.e. $5-35 \mathrm{Kg}_{\text {COD }} \mathrm{m}^{-3} \mathrm{~d}^{-1}$ ), the UASB attained COD removal levels higher than $70 \%$. The first-order kinetics were found to be suitable for representation of the substrate removal. The kinetic constant decreased from 23 to 21 and $19 \mathrm{~d}^{-1}$ at 37,30 and $25{ }^{\circ} \mathrm{C}$ respectively. Prediction of effluent COD and methane production rate during continuous reactor operation was possible using the first-order kinetic model.

KEYWORDS: anaerobic digestion; fruit wastewater; granular sludge; UASB; first-order kinetics.

\section{INTRODUCTION}

The fermentative production of methane from organic compounds is accomplished by an-association of methanogenic bacteria (Hulshoff Pol et al., 2004). Biomass quality and characteristics are susceptible to alterations both in space and time as a consequence of operational and environmental conditions (wastewater characteristics, hydraulic retention time, temperature, $\mathrm{pH}$, turbulence, etc) (Skiadas et al., 2003).

Successful operation of anaerobic treatment systems is crucial both for environmental protection (water purification) and energy recovery. In full scale applications, plant operator may regulate the wastewater flow into the reactor based on 3 sets of data i.e.: the raw water characteristics (analytical methods), the biogas production rate and composition (on-line data acquisition) as well as effluent characteristics (analytical methods). Reactor operational $\mathrm{pH}$ and temperature are usually maintained at optimum level by appropriate equipment. Biomass concentration and characteristics are also important parameters for optimum operation. However, in industrial practice relevant analytical methods are limited and the operator relies on sludge activity and microscopic observations.

Modelling of the anaerobic processes is an interesting exercise for design, prediction and control purposes (Muller et al., 1997; Pullammanappallil et al., 1998; Lyberatos and Skiadas, 1999; Gavala et al., 2003). The Monod model is efficiently applicable for the description of organic matter removal during anaerobic digestion. Under these conditions, at low effluent substrate concentration, which is correlated to high reactor performance, the kinetics are first-order (Aivasidis and Diamantis, 2005). The first-order model is popular, simple and has been successfully applied both for wastewater and solid waste treatment processes (Alvarez et al., 1993; Borja and Banks, 1994; Gunaseelan, 2004). The first-order kinetic constant, $\mathrm{K}$, is related both to waste water type (pre-acidified or not, complex or soluble) and operational conditions (biomass concentration, temperature, $\mathrm{pH}$, etc). Gunaaseelan (2004) determined $\mathrm{K}$ values equal to $0.016-0.122 \mathrm{~d}^{-1}$ for different types of fruit solid wastes. A slightly higher value $\left(0.176 \mathrm{~d}^{-1}\right)$ was reported by Alvarez et al. (1993) using separated phase batch anaerobic digestion of fruit and vegetable wastes. A study from Borja and Banks (1994) with a non- 
acidified fruit wastewater revealed that the kinetic constant was between 0.9-4.7 $\mathrm{d}^{-1}$, in relation to the support used for microbial immobilization. The experiments were performed in batch reactors, at 35 ${ }^{\circ} \mathrm{C}$ and biomass concentration was maintained at 8.5-8.9 $\mathrm{gvss}^{-1}$.

In the present paper the first-order kinetic model was applied on a pilot-scale UASB reactor fed with a pre-acidified fruit wastewater, since relevant data were not detected in the literature. The kinetic constant was determined at three different operational temperatures $\left(37,30\right.$ and $25^{\circ} \mathrm{C}$ ). Aim of the paper was to examine the efficiency of the first-order kinetic model to predict UASB reactor performance under continuous operation (in terms of COD removal and methane production).

\section{MATERIALS AND METHODS}

\section{Wastewater characteristics}

The wastewater was prepared daily by diluting $20 \mathrm{ml}$ of peach nectar and pulp per $\mathrm{L}$ of tap water; total $\left(\mathrm{COD}_{\text {Tот }}\right)$ and soluble-COD $\left(\mathrm{COD}_{\mathrm{SOL}}\right)$ were maintained at $3420( \pm 100)$ and $3170( \pm 130) \mathrm{mg}_{\mathrm{COD}}$ $\mathrm{L}^{-1}$ respectively. The wastewater was stored into a plastic tank at $4{ }^{\circ} \mathrm{C}$. Nutrients and trace metals were added into the storage tank to ensure that no limitation occurs (concentration in $\mathrm{mg} \mathrm{L}^{-1}: \mathrm{N}=170$; $\mathrm{P}=30 ; \mathrm{S}=20 ; \mathrm{K}=40 ; \mathrm{Ca}=20 ; \mathrm{Mg}=10 ; \mathrm{Fe}=5 ; \mathrm{Cu}=0.10 ; \mathrm{Zn}=0.20 ; \mathrm{Mn}=0.10 ; \mathrm{Ni}=0.07 ; \mathrm{Co}=0.02 ; \mathrm{Mo}=0.01$; $\mathrm{Se}=0.07 ; \mathrm{B}=0.05)$.

\section{Experimental setup}

The pilot plant facility (Figure 1) comprised of a CSTR for wastewater acidification with variable working volume (2-10 L) and a sequential UASB reactor having an operational volume equal to $2 \mathrm{~L}$.
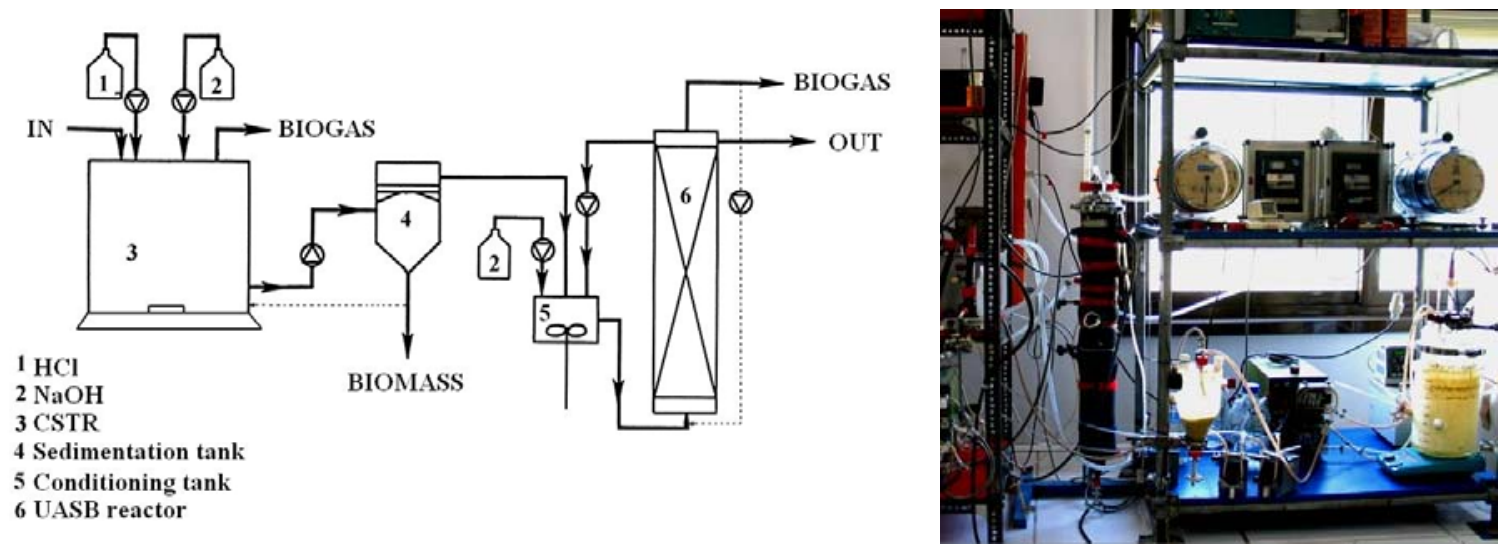

Figure 1. Experimental setup of the UASB reactor with separated acidification for the anaerobic treatment of synthetic fruit wastewater.

The effluent from the acidification stage with a pH of 3.75 was introduced continuously (after removal of suspended solids in a sedimentation tank) into the methane reactor. The $\mathrm{pH}$ of the UASB influent was regulated at 6.6 by aqueous solutions of $\mathrm{NaOH}$ and $\mathrm{HCl}$, which were dosed into a $0.1 \mathrm{~L}$ conditioning tank. The latter was installed on the UASB recycle stream and was equipped with a magnetic stirrer. UASB recycle flow and the substrate was fed into the conditioning tank using peristaltic pumps.

The study was conducted at mesophilic conditions at $36.5( \pm 0.6), 29.8( \pm 0.3)$ and $24.4( \pm 0.3){ }^{\circ} \mathrm{C}$. At each operational temperature, the performance of the pilot plant was assessed at sequentially increasing volumetric loading rates from 5 to $35 \mathrm{Kg}_{\mathrm{COD}} \mathrm{m}^{-3} \mathrm{~d}^{-1}$ ). The biomass concentration inside the UASB was maintained at $14.7( \pm 1.4) \mathrm{Kgvss}^{-3}$ reactor volume by regularly removing excess sludge. 


\section{Analytical methods}

The following parameters were monitored according to the APHA (1998): $\mathrm{pH}$, total suspended solids, total volatile solids, COD. $\mathrm{COD}_{\mathrm{SO}}$ was determined after filtering the samples with $0.45 \mu \mathrm{m}$ membranes. $\mathrm{COD}_{\text {TOT }}$ was determined after homogenization of the samples. The VFA (acetic, propionic, n-butyric, i-butyric, n-valeric) and ethanol concentrations were determined by Capillary Gas Chromatography (Diamantis et al., 2006). Biogas flow rate was determined by a wet gas-meter (Ritter Kunstoffwerk KWU B). The methane and carbon dioxide percentages in the biogas were measured with an IR Gas Analyzer (BINOS, Leybold-Heraues $\mathrm{GmbH}$ ).

\section{RESULTS AND DISCUSSION}

\section{Determination of kinetic constants}

The first-order kinetics is represented by the following equation:

$$
\mathrm{R}_{\mathrm{RS}}=\frac{\mathrm{dS}}{\mathrm{dt}}=\mathrm{K} \cdot \mathrm{S}_{\mathrm{e}}
$$

where:

$R_{R S}=$ volumetric substrate removal rate $\left(K_{c o D r} m^{-3} d^{-1}\right), K=$ first-order kinetic constant $\left(d^{-1}\right), S_{e}=$ effluent substrate concentration $\left(\mathrm{Kg}_{\mathrm{COD}} \mathrm{m}^{-3}\right)$.

Using equation (1) it is possible to determine the kinetic constant, $\mathrm{K}$, as shown below:

$$
\mathrm{K}=\frac{\mathrm{R}_{\mathrm{RS}}}{\mathrm{S}_{\mathrm{e}}}=\frac{\left(\mathrm{S}_{0}-\mathrm{S}_{\mathrm{e}}\right)}{\mathrm{T}} \cdot \frac{1}{\mathrm{~S}_{\mathrm{e}}}=\frac{\left(\mathrm{S}_{0}-\mathrm{S}_{\mathrm{e}}\right) \cdot \mathrm{Q}}{\mathrm{V} \cdot \mathrm{S}_{\mathrm{e}}}
$$

where:

$\mathrm{S}_{\mathrm{O}}=$ influent substrate concentration $\left(\mathrm{Kg}_{\mathrm{COD}} \mathrm{m}^{-3}\right), \mathrm{T}=$ hydraulic retention time $(\mathrm{d}), \mathrm{V}=$ reactor volume $\left(\mathrm{m}^{3}\right), \mathrm{Q}=$ wastewater flowrate $\left(\mathrm{m}^{3} \mathrm{~d}^{-1}\right)$.

In practice, the kinetic constant, $K$, is derived from the slope of the line of $R_{R S}$ versus $S_{e}$ using experimental data from different steady-state conditions. As shown in Figure $2 a$ the values of $K$ were determined equal to 23,21 and $19 \mathrm{~d}^{-1}$ at 37,30 and $25{ }^{\circ} \mathrm{C}$ respectively. These values are significantly higher than those reported by Borja and Banks (1994) (0.9-4.7 $\left.\mathrm{d}^{-1}\right)$ and this can be attributed to the different testing conditions (wastewater pre-acidification, higher biomass concentration).

The volumetric methane production rate $\left[\mathrm{R}_{\mathrm{CH} 4},\left(\mathrm{~m}^{3}{ }_{\mathrm{CH} 4} \mathrm{~m}^{-3} \mathrm{~d}^{-1}\right)\right]$ is given by equation (3):

$\mathrm{R}_{\mathrm{CH} 4}=\mathrm{Y}_{\mathrm{CH} 4} \cdot \mathrm{R}_{\mathrm{RS}}=\mathrm{Y}_{\mathrm{CH} 4} \cdot \mathrm{L}_{\mathrm{RS}} \cdot \mathrm{U}_{\mathrm{S}}$

where:

$\mathrm{Y}_{\mathrm{CH} 4}=$ methane selectivity coefficient $\left(\mathrm{m}^{3} \mathrm{CH}_{4} \mathrm{~kg}_{\mathrm{CODr}}^{-1}\right), \mathrm{L}_{\mathrm{RS}}=$ volumetric COD loading rate $\left(\mathrm{kg}_{\mathrm{CODo}} \mathrm{m}^{-}\right.$ ${ }^{3} \mathrm{~d}^{-1}$ ) and $\mathrm{U}_{\mathrm{S}}=$ COD removal (-). The $\mathrm{Y}_{\mathrm{CH} 4}$ coefficient is determined from the slope of the line of $\mathrm{R}_{\mathrm{CH} 4}$ versus $R_{R S}$ using experimental data from different steady-state conditions.

According to Figure $2 \mathrm{~b}$ the methane selectivity coefficient is equal to $0.324,0.302$ and $0.287 \mathrm{~m}^{3} \mathrm{CH} 4$ $\mathrm{kg}_{\mathrm{CODr}}^{-1}$ at 37,30 and $25^{\circ} \mathrm{C}$ respectively. Among these values, especially the one obtained at $37^{\circ} \mathrm{C}$,

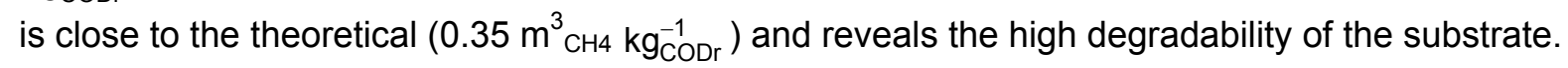

\section{Process simulation}

In full scale anaerobic digesters, the volumetric COD loading rate (Figure $3 a$ ) is determined by the raw wastewater COD concentration $\left(\mathrm{kg} \mathrm{m}^{-3}\right)$ and the hydraulic retention time (d) or wastewater flowrate $\left(\mathrm{m}^{3} \mathrm{~d}^{-1}\right)$. After determining the kinetic constant $\mathrm{K}$, using experimental data at different operational conditions (e.g. flowrate, temperature, biomass concentration, wastewater strength), the reactor effluent $\operatorname{COD}\left(S_{e}\right)$ and $C O D$ removal $\left(U_{S}\right)$ can be calculated as follows:

$$
\begin{aligned}
& S_{e}=\frac{S_{0} \cdot Q}{Q+K \cdot V} \\
& U_{S}=\frac{K \cdot \tau}{1+K \cdot \tau}
\end{aligned}
$$


In Figures $3 c$ and $3 d$ the estimated and measured values of effluent $C O D$ and $C O D$ removal are presented. It is evident that using the first-order kinetic model it is possible to predict reactor performance in terms of substrate removal. Furthermore, using equation (3) it is possible to estimate the volumetric methane production rate from the experimentally determined volumetric COD loading rate, the $\mathrm{Y}_{\mathrm{CH} 4}$ coefficient (see section 3.1) and the simulated COD removal values. In Figure 4 the experimental and simulated values of $\mathrm{R}_{\mathrm{CH} 4}$ during continuous reactor operation are presented. As shown, a slight deviation from the actual values occurs especially during reactor start-up period (initial $7 \mathrm{~d}$ ). This is attributed to the gradual increase of biomass concentration, which was under starvation for 14 months before the beginning of the experiments. The quantity of VSS per L of settled sludge was $34( \pm 4)$ and $62( \pm 19) \mathrm{gvss}^{-1}$ before start-up and at the end of the experimental period respectively.
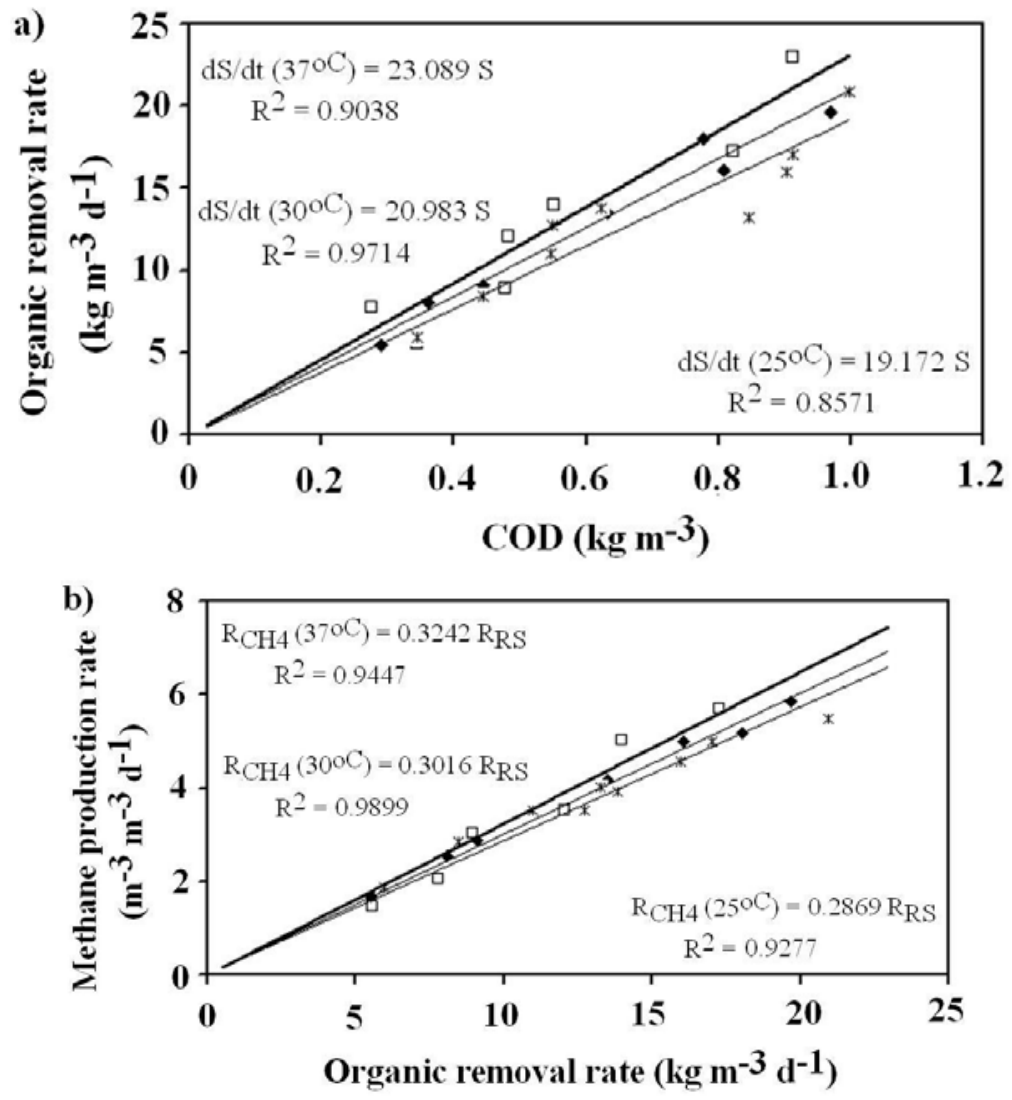

Figure 2. Volumetric substrate removal rate as a function of effluent substrate concentration (a) and volumetric methane production rate as a function of the volumetric COD removal rate (b) at $37(\square), 30(\bullet)$ and $25^{\circ} \mathrm{C}\left({ }^{*}\right)$

\section{CONCLUSIONS}

The degradation of a pre-acidified fruit wastewater was studied on the basis of UASB reactor. Firstorder kinetic model was found to be suitable for representation of substrate removal data. Prediction of reactor operation was possible. 

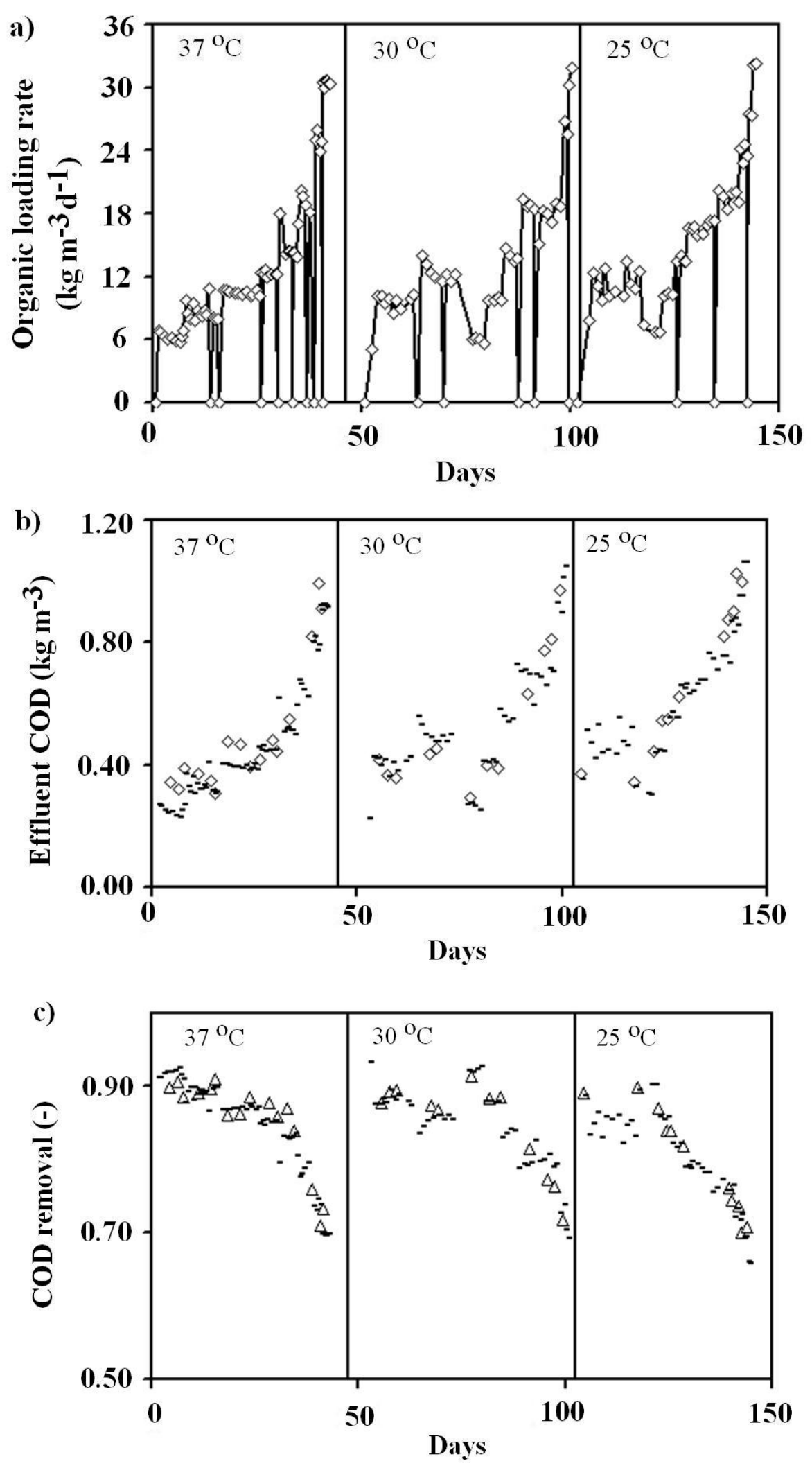

Figure 3. Actual volumetric COD loading rate (a), effluent COD (b) and COD removal (c) during continuous reactor operation [Estimated (---), measured values $(\diamond, \Delta$,$) ]$ 


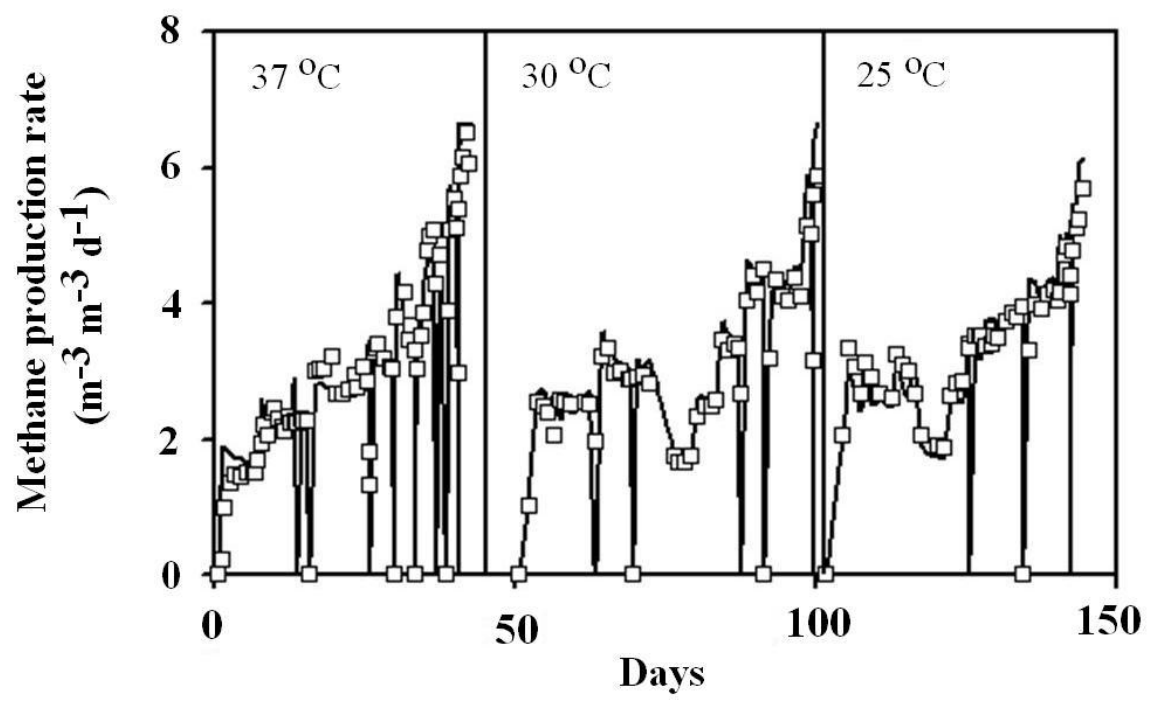

Figure 4. Actual ( $\square$ ) and simulated (-) volumetric methane production rate during continuous reactor operation

\section{REFERENCES}

Aivasidis A. and Diamantis V.I. (2005), Biochemical reaction engineering and process development in anaerobic wastewater treatment, Adv Biochemical Eng/ Biotechnol, 92, 49-76.

Alvarez J.M., Viturtia A.M., Luengo P.L. and Cecchi F. (1993), Kinetic and performance study of a batch two-phase anaerobic digestion of fruit and vegetable wastes, Biomass Bioenergy, 5, 481-488.

APHA (1998), Standard Methods for the Examination of Water and Wastewater, 20th edition. American Public Health Association, Washington, DC.

Borja R. and Banks C.J. (1994), Kinetic study of anaerobic digestion of fruit processing wastewater in immobilized-cell bioreactors, Biotechnol Appl Biochem, 20, 79-92.

Diamantis V.I., Melidis P. and Aivasidis A. (2006), Continuous determination of volatile products in anaerobic fermenters by on-line capillary gas chromatography, Anal Chimica Acta, 573-574, 189-194.

Gavala H.N., Angelidaki I. and Ahring B.K. (2003), Kinetics and modeling of anaerobic digestion process, Adv Biochemical Eng/Biotechnol, 81, 57-93.

Gunaseelan V.N. (2004), Biochemical methane potential of fruits and vegetable solid waste feedstocks, Biomass Bioenergy, 26, 389-399.

Hulshoff Pol L.W., de Castro Lopes S.I., Lettinga G. and Lens P.N.L. (2004), Anaerobic sludge granulation, Water Res, 38, 1376-1389.

Lyberatos G. and Skiadas I.V. (1999), Modelling of anaerobic digestion - a review, Global NEST, 1, 6376.

Muller A., Marsili-Libelli S., Aivasidis A., Loyd T., Kroner S. and Wandrey C. (1997), Fuzzy control disturbances in a wastewater treatment process, Water Res, 31, 3157-3167.

Pullammanappallil P.C., Svoronos S.A., Chynoweth D.P. and Lyberatos G. (1998), Expert system for control of anaerobic digesters, Biotechnol Bioeng, 58, 13-22.

Skiadas I.V., Gavala H.N., Schmidt J.E. and Ahring B.K. (2003), Anaerobic granular sludge and biofilm reactors, Adv Biochemical Eng/Biotechnol, 82, 35-67. 